\title{
REFLECTIVE ABILITIES OF STUDENTS: WAYS AND MEANS OF DEVELOPMENT WHILE STUDYING GEOMETRY
}

\author{
Natalia Podkhodova \\ Herzen State Pedagogical University of Russia, Russia \\ Helen Fefilova \\ Voronin Arctic Maritime Institute, Russia \\ Natalia Mikusheva \\ Department of Education of the Pushkin District Administration of St. Petersburg, Russia
}

\begin{abstract}
A reflective ability as an ability to comprehend one's experience, knowledge, evaluations is a psychological condition of thinking activity. But in researches, reflection is mainly considered as an indicator of a high level of thinking, creativity, the ability to analyze, types of reflection are not distinguished. For teaching mathematics, the development of intellectual reflection is especially important. In our study, the problem of the development of intellectual reflection is identified as an independent one. As a means of its development, we proposed geometric "many-valued" problems in which a situation of choice is organized. Three levels of development of reflective abilities in teaching geometry, in accordance with certain types of reflection are distinguished. The purpose of the study is to find out whether the level of development of students' reflection will change if "many-valued" problems are used in geometry. Is there a correlation of the manifestation of reflection on the geometric content and the content of another object? The experiment involved 375 students. The Pearson criterion was used in processing the results. The inclusion of "many-valued" problems in teaching geometry showed an increase in the level of formation of reflective skills of students and the transfer of these skills to another subject.
\end{abstract}

Keywords: levels of development of reflective abilities, "many-valued" problems, reflective abilities, students in grades 7-9, teaching geometry, a situation of choice.

\section{Introduction}

Awareness of the methods and means by which the student's educational activities are carried out, the ability to adequately assess their achievements and capabilities, to draw conclusions about their own improvement is the key to the successful development and training of students in both mathematics and other subjects. Reflection is one of the mechanisms that provides the conditions for achieving these goals. Development of intellectual type of student reflexing (ability to analysis of mental activity) is the key for successful development and 
Podkhodova et al., 2020. Reflective Abilities of Students: Ways and Means of Development while Studying Geometry

learning math. But the ability to realize reflective control does not develop without purposeful training (Vygotskij, 2006) The mechanism of inclusion of such analysis in the cognitive processes is the situation of choice, it promotes to take more effective control of the behavior and thinking (Glasser, 1989). Therefore, as an instrument for developing students' reflective abilities while studying mathematics, we proposed geometric problems (we called them "many-valued" problems) in which the multi meaning of each problem component (each component has more than one meaning) creates a situation of choice: the methods of solution; the selection of a specific set of conditions, each of them leads to its specific answer, including the non-existence of the given figure. We worked out sets of problems and the requirements for working with them. We distinguished three levels of development of reflective ability in teaching geometry, in accordance with certain types of reflection: extensive, intensive, constructive. The research questions are:

- Will the level of development of students' reflective abilities be changed if "many-valued" problems are used in studying geometry in accordance with certain requirements?

- Will the transfer on other school subjects be carried out (i.e. is there a correlation of the demonstration of reflexive abilities on geometric material and on the material of another subject)?

The study involved 147 students in control classes and 228 - in experimental. Unlike the control classes the students in the experimental classes solved the "many-valued" problems within the studied topic at the lessons of geometry (twice a week). The findings indicate that the effectiveness of the formation of levels 2 and 3 of reflection of students' reflexive ability in the experimental classes is statistically significantly higher than in the control ones $\left(\kappa^{2}=47.45, d f=1\right.$, $\rho<0.01$ ). Level detection of development of reflexive ability among students of experimental classes on geographical material showed a high degree of correlation. The number of students with the same level of reflective abilities differed by $1-2 \%$ while working with geographical and with mathematical material. "Many-valued" problems include tasks the solution of which involves operating the object mental image without a visual basis (all actions with the object are performed mentally).

\section{Literature review}

Due to the importance and role of reflection in cognitive activity, many researchers have studied this concept. Even D. Locke (Locke, 1960) considered reflection as a mechanism by which a person explores his cognitive activity. In his work, reflection is described as observation of mental activity, as well as ways of its manifestation are presented. A.P. Ogurtsov (Ogurcov, 2011) understands 
reflection as "thinking about thinking," as thinking that has made itself an object of knowledge. I.S. Ladenko defines reflection as "a critical awareness of one's own capabilities and the capabilities of other and those or other means of intelligent systems" (Ladenko, 1989, p.35) as a guarantor of positive interpersonal contacts, ensuring mutual understanding and coordination of people's actions in conditions of joint activity. Thus, in the context of philosophical problems, reflection is interpreted as the ability of the mind and thinking to turn on itself; analysis of knowledge in order to obtain new knowledge; self-observation of the state of mind and soul. Yu.N. Stepanov, V.K. Zareckij, I.N. Semenov (Semenov, Zareckij \& Stepanov, 1979) define reflection as a psychological mechanism. They consider the reflective component in the structure of thinking, taking into account the inclusion of the personal aspect in it. Reflection is connected with the spiritual world of a person, his ability to comprehend and rethink his experience, knowledge, assessments, is not only a general psychological condition for the course of any mental activity, but also acts as a central point (along with intuition) of the creative process (Semenov, 1990).

Among research in the field of education, the main problem is finding ways, means of developing reflective abilities. So, in a study (Strakova \& Cimermanova, 2018), ways of developing reflection of future teachers are considered. As a tool, a technologically supported environment is proposed. It is defined in the educational context as a workspace with new opportunities for acquiring learning experience. The role of computer technology in the development of students' reflective abilities is studied in the research (Zehavi \& Mann, 2005). In it the functions of reflective thinking are considered: in the choice of methods, monitoring of the decision process, understanding and conceptualization, in the creation of instrumental methods for solving problems in analytical geometry with CAS - Computer Algebra System. In the study (King, 2002), the formation of reflection in the learning process is based on familiarizing students with the features of reflection, using the model of stages of reflection and further evaluating students' reflexive writing for quality. The study (Porter, 1998) is aimed at solving the problem of developing critical reflective thinking based on problem-based learning in a model of joint (group) research. "Collaborative learning is a powerful and attractive strategy worthy of thoughtful application by all high school teachers". (p. 38) The development of reflective thinking through collaboration and philosophy is also proposed in the study (Chesters, 2012). The Socratic class presents a theoretical and practical study of how philosophy can be accepted in education. He implements three different approaches that make a significant contribution to classroom practice: the Matthew Lipman Investigation Community, Leonard Nelson's Socratic Dialogue, and David Bohm's Dialogue and reflects Socratic pedagogy, which relies on the "generative, evaluative, and connecting thinking" that is inherent in reflective thinking. 
Podkhodova et al., 2020. Reflective Abilities of Students: Ways and Means of Development while Studying Geometry

As for the development of student's reflective abilities different researchers suggest different ways to achieve the task. It may be a specific approach to the organization of training, a model or technology of training. For example, the study (Porter, 1998), is aimed at solving the problem of developing critical reflective thinking based on problem-based learning in a model of joint (group) research. "Co-education is a powerful and attractive strategy worthy of thoughtful application by all high school teachers" (Porter, 1998, p.38). In the study (Shikhova, 2005) the basis for constructing the educational process is a problematic approach to learning in a primary school, and the techniques, methods and forms of organizing educational activities are aimed at solving the problem of self-development in the study of chemistry. It can also be certain sets of tasks, but with the organization of a dialogue between students and a teacher or between students themselves. In the study (Shatova, 2004) solving logical problems within the framework of a dialogue is proposed as a means of developing the reflexive activity of students in grades 5-6. Kotenko identified a certain type of tasks reflective, i.e. problems "activating the process of reflection various components of educational activity by students" (Kotenko, 2000, p.15). The author considers these tasks as aimed at improving the learning ability of schoolchildren in computer science lessons. In our opinion, these are not tasks in the generally accepted sense, but tasks focused on the assimilation of theoretical material, work with concepts and types of tasks. In the study of geometry, some researchers (Patronis, 1990) offer work with models as a means of developing reflective thinking. In other studies, for example, (Ulmer, 2015), on the contrary, situations requiring reflective thinking are used to transfer of reasoning ability from subject matter fields to more general fields, and also to improve the quality thinking by making use of the opportunity offered in geometry to study principles of reflective thinking. Many applications of reflective thinking (Ulmer, 2015, p.13) were considered in both geometric and non-geometric situations.

But in these works, the problem of the development of reflection is mainly considered as an indicator of a high level of theoretical thinking, creative thinking, conscious skills, characterized primarily by the ability to analyze. In these works, the question is not raised, what is the difference between reflection and analysis, there is no tool for evaluating the reflection level, the level of mastery of knowledge or skills is most often checked. Also, the variety of manifestations of reflection, the features of its deployment as an integral act, are not taken into account. This means that the problem of the development of reflection is not identified as independent, requiring special study, although most psychologists consider it as an independent task. All of the above determines the relevance and novelty of the research problem, which consists in the search for means of developing intellectual reflection as an integral act in teaching geometry to students in grades 7-9 and identifying levels of proficiency in it. 
It is important to understand that the possession of reflection should not be manifested only on geometric material, it should be a universal skill that does not depend on the content in question. The possibility of such a transfer was shown back in a study (Cook, 1943): after teachers were developing students' logical reasoning through geometry during a year the students could use that same type of thinking in situations outside of geometry.

We also have developed definite means for developing reflective abilities while teaching geometry, so it is necessary to seek evidence that students will manifest these abilities outside of geometry.

\section{Methodology}

The analysis of the literature showed that reflection begins to form in primary school age (Davydov, 1986). But adolescence is characterized by active selfconsciousness (Bizyaeva, 2004.). Therefore, it is advisable to develop reflection in students in grades 7-9. Psychologists distinguish such types of reflection as intellectual (associated with the subject's ability to reflect on knowledge, the subject and ways of acting with it) and personality (associated with the subject's investigation of himself, his own personality as a person). (Semenov, 1990). When teaching geometry, conditions are created for the development of intellectual reflection, on the one hand, and on the other, its development is necessary, for the ability to solve geometric problems.

Intelligent reflection manifests itself in such forms as:

1) extensive reflection (associated with the control and planning of transformations of the content or operations that are obvious to the subject, with the fixation of the performed action and the relationship to subsequent actions);

2) intense thinking (the subject discovers ambiguities in the contents of the assignment, errors in operations and eliminates them thanks to an understanding of the problem);

3) constructive reflection (organizes the integrity of the stream of thought processes, it is necessary to determine the correct solution to the problem). These types of reflection are in a certain hierarchy, constructive is considered as the highest type (Zaretsky, Semenov, \& Stepanov, 1979). In order to develop reflection and to trace its formation in the learning process, we have developed criteria for the development of reflection in geometry training, taking into account the hierarchy of types of intellectual reflection.

The student can solve the problem in one or two steps in accordance with the model and substantiate his decision. He understands what he knows and what he does not know. This is characteristic of manifestations of extensive reflection, 
Podkhodova et al., 2020. Reflective Abilities of Students: Ways and Means of Development while Studying Geometry

which, in accordance with the hierarchy of types of intellectual reflection, characterizes the lower level of its development. Therefore, we have defined this level as the first level of development of intellectual reflection in teaching geometry.

The student can solve the problem in several stages and justify the solution, in case of difficulty determines the boundaries of his knowledge, but when solving a multi-stage task, he can plan a part of the solution and only after its implementation. continue the decision. This is characteristic of intense reflection. Therefore, we have defined this level as the second level of development of intellectual reflection.

The student is able to formulate a plan for solving the entire problem, justify, offer the final result. This allows him to determine all stages of the solution. This is characteristic of manifestations of constructive reflection. Therefore, we have defined this level as the third level of development of intellectual reflection.

The development of students' reflection with the help of geometry is possible only if there is knowledge of the basic geometric facts necessary for solving problems. Therefore, we determined the basic (zero) level of development of reflection in teaching geometry (a student can solve the problem in one or two stages according to the algorithm, but cannot explain the reason for the difficulties, determine the boundaries of his knowledge).

In contrast to analysis, reflection occurs simultaneously with mental activity, and not delayed and represents a holistic act. Four stages of the formation of reflection in educational activity as a holistic act were singled out by us on the basis of a consideration of the characteristics of the flow of reflective processes in learning, identified by V. Bogin, A.V. Khutorsky and others.

1. The stage of a complete stoppage of activity. Activities that are being completed or terminated. If during the solution of a problem there is a difficulty, doubt in the way of solution, then the solution is suspended.

2. The stage of stopping activity. The student understands that the subject activity is stopped, and tries to find out the reasons for the situation.

3. The stage of objectification. The student turns to restoring and studying the sequence of actions performed.

4. The stage of generalization of the content. Identification of the results of reflective activity, which may be:

a) ideas, answers to questions, etc .;

b) the methods that were used in the course of the activity;

c) hypotheses in relation to future activities.

The completion of the student's reflexive activity is the testing of hypotheses in practice in subsequent substantive activity.

The mechanism of inclusion in cognitive processes of reflection is the situation of choic (Glasser, 1998). Therefore, as a means of developing reflection 
in teaching geometry, we chose problems that are aimed at developing a multivalued vision that requires a choice. We called such problems (tasks) "ambiguity problems (tasks)". The ambiguity of each structural component of the problem allows you to create a situation of choice: a solution; justification; highlighting a specific set of conditions, each of which leads to its own specific answer, including the non-existence of a given object. Moreover, the ambiguity of the condition can be expressed explicitly and implicitly. In accordance with the structural components, task types were identified.

We give examples of «many-valued» problems.

Example 1. Type: problems related to the ambiguity of the answer. The condition for such problems contains an explicit situation of choice. The task proposes solutions made by someone, it is necessary to explain how they were received. This makes the decider try to understand the mental activity of another. Problems of this type characterize the development of the first level of reflection, since their solution consists of one or two steps and is associated with objective actions that are obvious to the student. Such activity is based on extensive reflection and initiates the development of intense reflection.

Problem 1. Students, having studied the drawings, came to the conclusion that trapezoids are depicted in fig. 1a), 1c), 1d). Do you agree with them? Explain why they drew such conclusions.
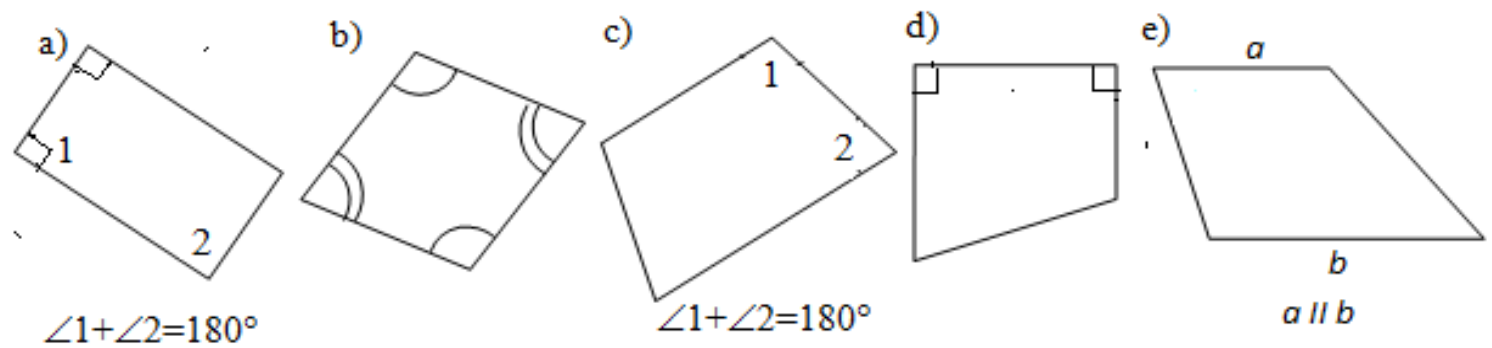

Figure 1 Images of quadrangles

Example 2. Type: problems in which the ambiguity of the condition is explicitly indicated. Such problems are mainly intended for the development of the third level of reflection, since they are aimed at planning a strategy for solving the problem as a whole, at predicting those features of the solution that will appear (or may appear depending on the introduction of certain additional data into the problem text). Work on such problems contributes to the development of constructive reflection.

Problem 2. In the isosceles trapezoid bases 14 and 8. Enter additional data so that you can find the side of the trapezoid.

Adding, for example, data such as "the bisector of the angle divides the side 
Podkhodova et al., 2020. Reflective Abilities of Students: Ways and Means of Development while Studying Geometry

opposite the vertex of the angle in the ratio of 3: 5”, leads to 6 situations, but some of the trapezoids do not exist.

Example 3. Type: problems "on the mental creation of the image."

Problems of this type are problems whose solution involves operating with an image of an object in the absence of a visual basis (all actions with the object are performed mentally) (Podkhodova, 2019). The answer can be presented in a drawing or orally described. The problems "on creating an image" include the translation of a word into an image, and the image is always subjective and ambiguous, which is explained by the unique experience of each person. The ambiguity of students' understanding of the text implies ambiguity in the state, methods of solution and justification. The ambiguity of the requirements is objectively embedded in the text of such problems. This polysemy creates situations of choice for students and requires an understanding of the basics of their actions, constant self-control over their own perception of the text and mental operations.

Problem 3. Imagine a rhombus before you. One side of it is horizontal. Mentally draw its diagonal from the left upper vertex to the right lower vertex. Bend your rhombus on this diagonal so that the upper right angle was put on the left lower one. Then find the middle point of the bend line. After that draw the segment from this point perpendicular to the horizontal line. Cut along this segment and put away the right part. Unfold the left part (your rhombus was folded) and draw the obtained figure. If solving of the problem is difficult for pupils they can do it practically

The problems "on creating an image" can be proposed when studying any topic in geometry, at any stage of the lesson with various goals. At the beginning of the lesson - for motivation; to consolidate the theoretical material; to verify the formed ideas about geometric figures and their essential properties at the level of images (suitable for right hemispheres students); contribute to the formation of a competent mathematical language. Their compilation by students contributes to the development of creative abilities, the ability to describe spatial relationships. We have developed eight requirements for the selection and design of tasks for the development and diagnosis of the level of development of students' reflection. One of the requirements for the problems corresponding to the second and third levels of reflection development is the use of preparatory tasks aimed not only at updating the knowledge necessary to solve the problem, but also at turning students to their mental activity when searching for a solution. The condition and requirement of problems aimed at the development of the third level, involves the study. The use of "many-valued" problems in the process of teaching geometry requires the organization of work with them, "the teacher must not only set the task, but also organize work to solve it” (I.S. Yakimanskaya, 2008). For the development of reflection among students as an integral act, we developed end- 
to-end (effective when working with the "ambiguity" task of all types) and specific (effective for working with specific types of "many-valued" problems ") methods.

\section{Research results}

Formative experiment lasted for a year. The performance in the control and experimental classes at the beginning of the experiment was approximately the same. Students in experimental classes solved the "many-valued" problems within the studied topic at the lessons of geometry (twice a week). The students in the control classes study geometry according to a traditional program.

Table 1 shows the distribution of students by levels of development of reflection before and after the formative experiment.

Table 1 Level of reflection development in teaching geometry

\begin{tabular}{|l|c|c|c|c|}
\hline \multirow{2}{*}{$\begin{array}{c}\text { Level of reflection } \\
\text { development }\end{array}$} & \multicolumn{2}{|c|}{$\begin{array}{c}\text { The number of students in } \\
\text { experimental classes (\%) }\end{array}$} & \multicolumn{2}{c|}{$\begin{array}{c}\text { The number of students in } \\
\text { control classes (\%) }\end{array}$} \\
\cline { 2 - 5 } & before & after & before & after \\
\hline Basic level & $22 \%$ & $0 \%$ & $26 \%$ & $23 \%$ \\
\hline First level & $53 \%$ & $32 \%$ & $46 \%$ & $47 \%$ \\
\hline Second level & $23 \%$ & $58 \%$ & $25 \%$ & $24 \%$ \\
\hline Third level & $2 \%$ & $10 \%$ & $3 \%$ & $6 \%$ \\
\hline
\end{tabular}

From the data given in the table 1, a positive shift is visible in the dynamics of the development of reflection of students in experimental classes. Moreover, positive changes in the development of reflection occurred in all students, with the exception of $2 \%$ of schoolchildren. $75 \%$ had an increase in the level of development of reflection by one level. $23 \%$ of students showed higher results in knowledge compared to traditional ones for themselves, although progress in the development of reflection in accordance with the selected criteria did not completely go one level. In the control classes, the level of development of reflection in students practically did not change.

Students of the experimental classes were also offered a diagnostic work on geography, compiled taking into account the levels of development of reflection. According to its results, it can be concluded that the transfer of students' ability to reflection when studying mathematics to another field of knowledge occurred (table 2). 
Podkhodova et al., 2020. Reflective Abilities of Students: Ways and Means of Development while Studying Geometry

Table 2 Level of reflection development in teaching geometry and geography after the formative experiment

\begin{tabular}{|l|c|c|}
\hline $\begin{array}{l}\text { Level of reflection } \\
\text { development }\end{array}$ & $\begin{array}{c}\text { The number of students in } \\
\text { experimental classes (\%) } \\
\text { Geometry }\end{array}$ & $\begin{array}{c}\text { The number of students in } \\
\text { experimental classes (\%) } \\
\text { Geography }\end{array}$ \\
\hline No basic level & - & $2 \%$ \\
\hline Basic level & - & $6 \%$ \\
\hline First level & $33 \%$ & $36 \%$ \\
\hline Second level & $58 \%$ & $50 \%$ \\
\hline Third level & $9 \%$ & $6 \%$ \\
\hline
\end{tabular}

The results obtained in the experimental and control classes were processed and compared before and after the completion of the formative experiment using the $\chi 2$ - Pearson criterion according to formula (1).

$$
\sum \frac{n_{i}-n_{i}^{\prime}}{2 n_{i}^{\prime}}
$$

where $n_{i}$ - the empirical frequencies obtained from the sample, $\mathrm{n}_{\mathrm{I}}^{\prime}$ - the theoretical frequencies found theoretically.

The application of this criterion was possible, because:

1) both samples are random;

2) the samples are independent, and the members of each sample are independent among themselves;

3) as a scale for measuring the level of development of reflection, a scale of names with four categories was selected;

4) more than 100 participants in the experiment.

\section{Conclusions}

As a result of the study, the effectiveness of the developed methodology for the development of students 'reflective abilities in grades 7-9 was confirmed in teaching geometry. "Many-valued" problems generated interest among students.

In the process of theoretical and experimental research, which consists in finding means of developing reflection in teaching geometry to students in grades 7 - 9, and in accordance with the purpose and objectives of the study, the following main results were obtained.

Based on the analysis of psychological and pedagogical literature:

1. The stages of the formation of reflection (in accordance with the structure of reflection as an integral act) in educational activities are characterized. 
2. Criteria for the development of reflection and, based on them, the levels of development of reflection, depending on the manifestations of various types of intellectual reflection (extensive, intense, constructive) in teaching geometry, are highlighted.

Based on these theoretical generalizations were:

1. Developed requirements for the selection and design of "many-valued" problems that contribute to the development of reflective abilities of students;

2. The types of "many-valued" problems, which contribute to the development of students' reflective abilities are highlighted.

3. A system of "many-valued" problems was developed, which contributes to the development of reflective abilities of students in grades 7-9 in teaching geometry.

4. A methodology has been developed for working with the task system, aimed at developing reflection of students in grades 7-9 in teaching geometry, including through and specific techniques for working with "many-valued" problems.

5. It is proved that students who manifest reflective abilities when working with geometric material also show them when working on other subjects.

\section{References}

Bizyaeva, A.A. (2004). Psychology of a thinking teacher: pedagogical reflection. PSPI named after S.M. Kirov. Pskov. Retrieved from https://dogmon.org/a-a-bizyaeva-psihologiyadumayushego-uchitelya-pedagogicheskay.html

Chesters, S.D. (2012). The Socratic classroom: reflective thinking through collaborative inquiry. Sense Publishers. Rotterdam; Boston.

Cook, I. (Febuary, 1943). Developing Reflective Thinking Through Geometry. The Mathematics Teacher, 36(2), 79-82.

Cukerman, G.A. (2010). Razvitie uchebnoj samostojatel'nosti. M.OIRO.

Davydov, V.V. (1986). Problems of developing education. M.

Glasser, W. (1998). Choice theory: A new psychology of personal freedom. New York: Harper Collins.

Il'jasova, A.B. (1997). Razvitie myslitel'nyh dejstvij uchashhihsja pri formirovanii ponjatij na urokah matematiki $v$ mladshih klassah shkoly: dis. ... kand. ped. nauk. M.

King, T. (2002). Development of Student Skills in Reflective Writing Article. Retrieved from https://www.researchgate.net/publication/251656887_Development_of_Student_Skills_ in_Reflective_Writing/citation/download

Kotenko, V.V. (2000). Refleksivnaja zadacha kak sredstvo povyshenija obuchaemost ishkol'nikov $v$ processe izuchenija bazovogo kursa informatiki: avtoreferat dis. ... kandidata pedagogicheskih nauk. Omsk. 
Podkhodova et al., 2020. Reflective Abilities of Students: Ways and Means of Development while Studying Geometry

Lavy, I. (2015). Problem-PosingActivities in a Dynamic Geometry Environment: WhenandHow. In: Singer F., F. Ellerton N., Cai J. (Eds.), Mathematical Problem Posing. Research in Mathematics

Locke, D. (1960). Experience about the human mind. Selected philosophical works: in 2 volumes M., V. 1.

Ogurcov, A. P. (2011). Filosofiya nauki. Dvadcatyjvek. Koncepcii I problemy. V 3 knigah. Izdatel'stvo: Mir.

Porter, L.K. (1998). Critical reflective thinking in Euclidean geometry for grade nine mathematics students. Master thesis, Memorial University of Newfoundland, 139-149

Patronis, T. (1990). Using geometrical models in a process of reflective thinking in learning and teaching mathematics. Educational Studies in Mathematics, 21(1), 29-54.

Podkhodova, N.S. (2019). Methods of teaching mathematics: in 2 Parts / under the editorship of N.S. Podkhodovoy and V.I. Snegurova. M: Yurayt Publisher House.

Refleksija v nauke i obuchenii: Sbornik nauchnyh trudov. (1989). Pod red. I. S. Ladenko. Novosibirsk: IIF-FSO

Rubinshtejn, S.L. (1989). Osnovy obshhej psihologii. V 2 t. M.: Pedagogika, T.1.

Russo, Zh-Zh. (1981). Pedagogicheskij sochinenija: V 2-h t.T1/ Pod red. G.N. Dzhibladze M.: Pedagogika.

Semenov, I.N., Zareckij, V.K., \& Stepanov, S.Ju. (1979). Produktivnost' refleksii pri diskursivnom reshenii zadach, Novye issledorvanija $v$ psihologii, 2, 7-12

Semenov, I.N. (1990). Ot gumanitarnoj refleksologii k tehnologicheskoj refleksike: tipologija refleksii i struktura refleksivnosti $\mathrm{v}$ organizacii tvorchestva. Refleksivnye process $i$ tvorchestvo, 20-22.

Shatova, N.D. (2004). Logicheskie zadachi kak sredstvo razvitija refleksivnoj dejatel'nosti uchashhihsja 5 - 6 klassov pri obuchenii matematike. Avtoref. Dis. nasoisk. uchen. step. k.p.n. spec. Omsk.

Shihova, L. N. (2005). Razvitie refleksivnyh umenij uchashhihsja v processe izuchenija himii v sovremennoj shkole. Avtoref. Dis. nasoisk. uchen. step. k.p.n. spec. Sankt-Peterburg.

Strakova, Z., \& Cimermanova, I. (2018). Developing reflective skills of student teachers in the virtual learning environment Electronic Journal of e-Learning, 16(2), 107-121. Retrieved from https://www.researchgate.net/publication/330192985

Ulmer, G. (2015). Teaching Geometry to Cultivate Reflective Thinking. An Experimental Study with 1239 High School Pupils, 18-25. DOI: https://doi.org/10.1080/ 00220973.1939 .11010143

Tonkykh, G.D. (2010). Rol' refleksii v processe obuchenija matematike v srednej shkole. Ucheny ezapiski. ZabGU s, 105-111.

Vygotskij, L.S. (2006). Psihologiya razvitiya rebenka. EKSMO.

Zehavi, N., \& Mann, G. (2005). Instrumented Techniques and Reflective Thinking in Analytic Geometry. The Mathematics Enthusiast, 2(2).

Yakimanskaya, I.S. (2008). Pedagogicheskaya psihologiya (osnovnyeproblemy). Moskva: MPSI. 